Article

\title{
Veridiction and Leadership in Transnational Populism: The Case of DiEM25
}

\author{
Evangelos Fanoulis ${ }^{1}$ and Simona Guerra ${ }^{2, *}$ \\ ${ }^{1}$ Department of International Relations, Xi'an Jiaotong-Liverpool University, 215123 Suzhou, China; \\ E-Mail: Evangelos.Fanoulis@xjtlu.edu.cn \\ 2 School of History, Politics and International Relations, University of Leicester, Leicester, LE1 7RH, UK; \\ E-Mail: gs219@leicester.ac.uk \\ * Corresponding author
}

Submitted: 3 October 2019 | Accepted: 16 January 2020 | Published: 5 March 2020

\begin{abstract}
While research tends to explore questions of power and leadership at the national level, populism in Europe has moved beyond national borders, with an increasing number of transnational movements and organizations. This article investigates the Democracy in Europe Movement 2025 (DiEM25) and its leadership's main speeches. Informed by both discourse theory and Michel Foucault's work on parrhesia (veridiction), the analysis draws on readings of transnational Euroalternativism and populism, pointing out the conflicting logic of bringing them together at the transnational level. Our findings thus stress the increasing politicization of European integration as an opportunity to mobilize transnational activities, which are based on the populist 'people vs. the elites' dichotomy and against Brussels' unaccountable elites (see FitzGibbon \& Guerra, 2019), while indicating the limits of leadership in a populist transnational movement (de Cleen, Moffitt, Panayotu, \& Stavrakakis, 2019; Marzolini \& Souvlis, 2016)
\end{abstract}

\section{Keywords}

discourse analysis; Euroalternativism; leadership; parrhesia; power relations; transnational populism

\section{Issue}

This article is part of the issue "Leadership, Populism and Power" edited by Cristine de Clercy (Western University, Canada).

(C) 2020 by the authors; licensee Cogitatio (Lisbon, Portugal). This article is licensed under a Creative Commons Attribution 4.0 International License (CC BY).

\section{Introduction}

The Democracy in Europe Movement 2025 (DiEM25) officially took off at the Volksbühne (the 'People's Theatre') in Rosa Luxembourg Platz, in Berlin, on Tuesday 9th February 2016. Since then, DiEM25 has developed as a pan-European political movement whose raison d'être is the democratization of the European Union (EU; Moffitt, 2017). The movement's founding fathers, former Greek finance minister Yanis Varoufakis and Croatian philosopher Srećko Horvat have presented European citizens with two simple choices regarding the EU's future. The institutions, policies and procedures of the EU will either become more democratic or the Union will disintegrate (DiEM25, n.d.-a). In the meantime, the EU's multiple crises have meant that DiEM25 now resonates with citizens across Europe who share disap- pointment and distrust in how the EU works (Panayotu, 2017). Its critical stances towards the EU-here defined as Euroalternative, as explained below-translated into electoral gains in the recent Greek national elections, where the movement's electoral wing, under the leadership of Varoufakis, gained $3.44 \%$ of the national vote and nine seats in the country's parliament ("Final results of Greek national elections," 2019).

The success of DiEM25 should be seen within the context of increasing populism in Southern Europe. Considering the EU technocrats and bureaucrats in Brussels to be suppressors of the citizens' voice in European governance (DiEM25, n.d.-b), the movement has embraced the populist dichotomist logic of people vs. the elites (Laclau, 2005a; Mudde, 2004; Stavrakakis, 2017). DiEM25's criticism of the EU is its primary political strategy, bringing together heterogeneous public de- 
mands, all under the people's concept (see also de Cleen, Glynos, \& Mondon, 2018). As argued elsewhere, the combination of a critical narrative towards the EU and a populist logic is not a new phenomenon in Southern Europe. It can be traced back to the national political successes of Podemos in Spain and Syriza in Greece (Fanoulis \& Guerra, 2017; Kioupkiolis \& Katsambekis, 2018). Yet, little research has been published regarding the combination of transnational opposition to European integration, termed Euroalternativism (FitzGibbon \& Guerra, 2019), and populism.

In order to fill this gap, our analysis examines the use of Euroalternativist discourses by the political leadership in transnational populism, using DiEM25 as its case study. Expanding on recent studies (de Cleen, Moffitt, Panayotu, \& Stavrakakis, 2019; Moffitt, 2017), our research question asks whether the movement's leadership has succeeded in constructing a transnational people by capitalizing on Euroalternative discourse. We also ask to what extent DiEM25's main political figure, Yanis Varoufakis, has managed to bring the peoples of Europe together by telling them the truth about the misdeeds and shortcomings of the EU. Using discourse theory and Michel Foucault's work on parrhesia (veridiction), our empirical investigation looks at the speeches of Varoufakis, trying to capture whether the political truth, as articulated by the movement's leader, has resonated with the peoples in the EU so much so as to construct one transnational people. Our main contention is that the pursuit of truth somehow gets stuck in the difficult passage from national to transnational populism. In terms of discourse theory, signifiers such as 'change the EU' or 'for a more democratic Europe' are used tendentially in Varoufakis' Euroalternativist discourse as unspoken truths. They can bring together the notion of the people, but also establish an internal frontier in Europe's social space between an 'us, the pan-European people' versus 'them, the Brussels' elites.' Thus, the focus of our study lies on how the movement's leader makes use of a Euroalternativist truth in order to establish a transnational European people.

The analysis will proceed as follows. Section 2 presents our theoretical framework, i.e., Laclau's basic concepts in his theory of populism and the Foucauldian notion of parrhesia. Section 3 revisits the emergence of DiEM 25 by rereading its manifesto, with topical emphasis on its references to populism and Euroalternativismhaving introduced the latter as a contemporary form of pro-systemic opposition towards the EU. Section 4 consists of a brief note justifying our methodological choices. In the section that follows, we present a discourse analysis of key speeches of Yanis Varoufakis, as the leader of DiEM25. Having elaborated on how the question of leadership affects the transnational expansion of DiEM25, the conclusion of this study addresses the weakness of shifting to a homogeneous people for a transnational populist movement and we underline the political potential of a progressive Euroalternativist movement speaking truth to power via its leader(ship).

\section{Laclau's Populism and Foucault's Parrhesia}

Laclau (2005a) developed an account of populism centred on key concepts of his discourse theory, namely logics of difference and equivalence, internal frontier and antagonism, and empty signifiers. First of all, Laclau presents populism as a distinct "political logic" (Laclau, 2005a, p. 117) and a "logic of articulation" (Laclau, 2005b, p. 33) that brings together heterogeneous public demands as they emerge in society. This process is both social and relational. As Laclau (2005a, p. 73) writes, "'the people' is not something of the nature of an ideological expression, but a real relation between social agents."

But how is it possible that highly diverse sociopolitical demands, coming from a plethora of societal actors with highly differentiated political identities can be jointly articulated? Two processes appear to happen in parallel, one based on a logic of difference and one on a logic of equivalence. On the one hand, public demands have to maintain their uniqueness in the societal realm so as satisfy the distinct groups or actors articulating them. On the other hand, their plurality gets acknowledged in a democratic society according to a logic of equivalence, that means they are understood to be of equal democratic importance (Laclau, 2005b).

In lines with populist reasoning, there needs to be some sort of pairing of these heterogeneous demands, whilst maintaining their 'particularity' to use Laclau's own words. This can occur by tying them up in a chain of equivalence. The chain of equivalence downplays the element of heterogeneity and socially constructs an analogy between the public demands, which is then able to keep them together. There is an inherent tension in this procedure, also acknowledged by Laclau (2005a, p. 122) "so the equivalential chain necessarily plays a double role: it makes the emergence of the particularism of the demands possible but, at the same time, it subordinates them to itself as a necessary surface of inscription."

Yet, for the equivalential chain to be able to subordinate the public demands to itself, it needs to recalibrate them around features they share even in their distinctive uniqueness. Simply put, there needs to be a kind of 'glue' that can stick the public demands together. For Laclau, this is done by means of introducing an internal frontier in the society, splitting the social space into two camps. The 'glue' that brings together the heterogeneous public demands is their common political aversion towards an antagonistic other, a common political adversary that does not allow for these demands to be satisfied (Laclau, 2005a, p. 131).

This 'glue' is the notion of the people for Laclau. The people is a signifier which aligns the heterogeneous public demands and does so by recognizing their common enemy that exists in society, yet is outside of the people's equivalential chain. The notion of the people thus 'hegemonizes' the meaning of the heterogeneous public demands by introducing them all under its signifier (Laclau, 2005a, pp. 132-133). At the same time, the 
people's own signifier is 'emptied' during this process (Laclau, 2005b).

The above abstract discussion has been summarized by post-Laclauian scholars in what is called the minimal definition of populism. As Stavrakakis and Katsambekis (2014, p. 123) note, a movement or party can be considered populist if it establishes the notion of the people, and does so based on an antagonistic logic of a "we, the people" versus an out-group that shares the same social space with the people yet is always outside of their group. What is striking in both Laclau and his followers' theorization of populism is the marginal attention to the role of political agency in populism and especially in relation to the role of the populist leader. Laclau (2005a, p. 99) has emphasized that his analytical schematization of populism is 'structural' and his elaboration of the populist leader follows the same pattern. However, an investigation of the populist leader necessitates looking more closely at questions of political agency. In this analysis, we consider that Foucault's notion of parrhesia, as it emerges in the French philosopher's governmentality approach, can help with such a task.

What we particularly focus on here is the linkages of parrhesia to populism on the one hand and leadership on the other. Translated into 'veridiction' or 'truth-telling' 'franc-parler' in the original French text-Foucault (2010, p. 52) argues that parrhesia is not simply the ontology of truth, but refers instead to the practice of telling the truth in a specific spatio-temporal context, where the parrhesiast-the agent standing up to tell the truth-is aware of the political risks and consequences that their outspokenness entails (Foucault, 2010, p. 56).

Parrhesia's basic features unravel in this definition. It is not just a performed act of truth or simply a speech act. As Luxon (2008, p. 379) highlights, "Foucault remains most interested in parrhesia as a concrete set of practices that condition the parameters of individual self-development." This set of practices is truthful not only because of being true but most importantly because the parrhesiastic subject freely and courageously chooses to speak the truth despite any unfavourable conditions or consequences for them due to the power nexus (Foucault, 2010, p. 66). As Foucault $(2010$, p. 66) attests, "parrēsia is the ethics of truth-telling as an action which is risky and free."

Foucault distinguishes between good and bad parrhesia, a distinction that he draws both politically and normatively. It is sometimes difficult to identify a clearcut definition of good parrhesia in his texts; the philosopher moulds our perception of it abductively, by giving examples of bad parrhesia such as flattery and demagoguery. Good parrhesiasts-philosophers like Socrates, or politicians like ancient Athens' Pericles-stand out in a demos of equals with an equal right to talk freely (isegoria), taking the floor and speaking the truth at their own risk. Hence, good parrhesia stands at a crossroads of ethics, knowledge, and power (Dyrberg, 2014).

This truthful set of practices results in various political relations which become meaningful in the context of a democratic polity. Firstly, there is the relationship of the parrhesiast to their own self, i.e., their commitment to be truthful and hence step beyond the existing power status quo in order to tell the truth. Secondly, there is the relationship that develops between the parrhesiast and the rest of the demos, what Foucault (2010) calls ascendancy and it clearly links to the question of political leadership in democracies. The parrhesiast emerges from the rest of the citizens with the ethical task of telling the truth to those who govern, hence acquiring a leadership position among their fellow citizens. And thirdly, there is the relationship between the parrhesiast and the political system itself, to which the parrhesiast addresses the truth. These three different relations constitute a form of pact, the "parrhesiastic pact," which for Foucault (2010, pp. $65-66,163$ ) is essential for the governing of oneself and of others in democratic politics.

Two aspects of the parrhesiastic pact are crucial for the ensuing investigation. The first is the linkage with the question of leadership. Parrhesia introduces a constitutive relationship between truth and the political agency of the leader. It bestows power and an ethical dimension upon this agency, which in turn become interconnected. By telling the truth in a free and unbinding manner, the parrhesiast's subject position in the power nexus changes, allowing them to govern others because of their being so truthful (to themselves) that they can first of all govern, and by doing so, form their own self (Foucault, 2011). What is more, the rising of the parrhesiastic leader is accompanied by an ontological bond to the truth with a profound ethical dimension. This means that their power to govern results from their normative pact to tell the truth both to the subjects as well as the rulers.

How does parrhesiastic leadership then connect with populism? Laclau's vision of the populist leader as "primus inter pares" (as cited in Mazzolini \& Borriello, 2018 , p. 242) coincides with Foucault's understanding of the parrhesiast. In populism's radical democratic politics, the parrhesiastic leader feels ethically compelled to tell the truth by becoming the people's voice. The populist leader addresses the truth in two consequential steps. First of all, the leader stands out from the rest of the citizens and raises awareness of the injustice, exploitation, and oppression experienced by unprivileged groups within a society. The leader then succeeds in bringing those heterogeneous public demands together in a chain of equivalence, under the common signifier of the people. At the same time, the parrhesiastic leader cements the notion of the people by accentuating the antagonistic relationship between this nascent people and its oppressors, i.e., the Establishment and economic and political elites (Stavrakakis \& Katsambekis, 2014).

\section{DiEM25 as a Euroalternative Transnational Movement}

In 2017, the year after the first steps of DiEM25 into European politics, John FitzGibbon, Benjamin 
Leruth, and Nick Startin (2017) published an edited volume on transnational Euroscepticism. The recent Eurozone crisis had impacted the increasing levels of dissatisfaction towards the EU, while the academic literature still seemed to focus on national, partybased Euroscepticism (Taggart, 1998; for hard and soft Euroscepticism, see Szczerbiak \& Taggart, 2002). With time, opposition has become more widespread and critical voices have additionally emerged in civil society (FitzGibbon, 2013). In order to explain the current protests, the volume modelled this new manifestation of pan-European opposition to the EU (Usherwood, 2017), where exogenous crises and events such as treaty reforms or the economic crisis, are significant factors affecting Euroalternativist mobilization beyond national borders. These crises may well explain the emergence of DiEM25 as a Euroalternative transnational movement and can be traced in its Manifesto, which states:

The Eurozone economies are being marched off the cliff of competitive austerity, resulting in permanent recession in the weaker countries and low investment in the core countries; EU member-states outside the Eurozone are alienated, seeking inspiration and partners in suspect quarters; unprecedented inequality, declining hope and misanthropy flourish throughout Europe. (DiEM25, n.d.-f)

Previous research has already argued that the tensions arising from European integration and the social costs of the EU's multiple crises have successfully mobilized discontent and contestation across different European countries (Fanoulis \& Guerra, 2017). At the domestic level, the anti-EU narrative has given voice to the citizens' dissatisfaction with national and EU elites, following a populist antagonistic logic of 'us' versus 'them.' DiEM25's antagonistic logic moves beyond national borders. It mainly revolves around the EU elites, such as the appointed technocrats of the European Central Bank, to defend democracy in countries that demonize the left of centre or do not pay real attention to the people against "corporate power" across Europe (DiEM25, n.d.-f). Moreover, in DiEM25 leader Yanis Varoufakis' view, there is no democracy in the EU. The EU thus needs to be reformed, otherwise it will implode and "we, the peoples of Europe, have a duty to regain control over our Europe from unaccountable 'technocrats,' complicit politicians and shadowy institutions" (DiEM25, n.d.-f).

Most importantly, DiEM25, shows a pro-systemic opposition towards the EU (FitzGibbon \& Guerra, 2019), and transnationally mobilizes citizens by asking for greater accountability and transparency. Such a critical view of European integration is defined as (progressive) Euroalternativism (FitzGibbon \& Guerra, 2019). Policies, not the polity, are at stake here. Euroalternativism, as pro-systemic contestation, emerged after the EU's economic and financial crisis. Due to the central reference to economic and social costs, Euroalternativism can be traced in DiEM25's manifesto that seeks "to subject the EU's bureaucracy to the will of sovereign European peoples; to dismantle the habitual domination of corporate power over the will of citizens, and to re-politicize the rules that govern our single market and common currency" (DiEM25, n.d.-f). Such critical voices are similar to the first 'Euro-critical' social movements and protests examined during the anti-austerity protests of 2011 (della Porta, Kouki, \& Fernández, 2017), signalling a loss of trust in both national and EU institutions. These movements did not call for a return to the nation-state, but a process of Europeanization from below. Similarly, DiEM25's call is to all EU citizens, the 'democrats' (in bold in the original below), and is not fully hostile to the EU. As mentioned on the movement's web-page, "committed democrats must resolve to act across Europe" (DiEM25, n.d.-f) as well as for Europe.

It is worth noting that DiEM25's progressive Euroalternativism is distinct from the radical right (and nationalist) approaches of sovereigntist altEuroalternativists, who "believe European cooperation can only work through the member states-even if the nature of the policy means that this must take place at the European level" (FitzGibbon \& Guerra, 2019). DiEM25 seeks to embrace all democrats across and beyond Europe. References, meetings and direct participation thus move beyond European borders, with affiliations to Noam Chomsky, Naomi Klein, and Bernie Sanders, with local DiEM25 Spontaneous Collectives (DSCs) and groups of volunteers also based in Australia and the United States (DiEM25, n.d.-g). As poignantly highlighted by Moffitt (2017), it is in the ambiguity of the passage from 'the people' to 'the peoples' that the construction of a transnational populist movement seems unsurmountable, as demands at the transnational level mainly emerge through national demands, with national characteristics. Yet, the analysis that follows stresses an emerging transnational progressive Euroalternativism intrinsic in DiEM25's and Varoufakis' populist discourse.

\section{A Note on Methodology}

Case study research is an effective methodology to examine and understand complex real-world issues. Central to this approach is the underpinning ontological and epistemological contribution gained through inductive analysis, which is the approach adopted here. Discourse theory, and Michel Foucault's work on 'parrhesia' will help us bring together the different dimensions of the case study and investigate the narrative and leadership discourse in DiEM25. Our empirical investigation focuses on 2019, being the most recent, and the year in which both the European Parliament (EP) elections and Greek general elections were held, alongside the rising salience of the Euroalternativist voice vis-à-vis the EU. The speeches were retrieved from the movement's official web-page (diem25.org) and the personal web-page of Yanis Varoufakis (yanisvaroufakis.eu). Concerning the 
latter, we initially collected all of Varoufakis' interviews from the year 2019 via his personal web-page. To reduce the amount of data, selection was limited to only those whose thematology was clearly centered on EU politics and European integration.

The analysis concentrates on the two most significant expressions of DiEM25's discourse, its progressive Euroalternativism and its populist dimension, as they together aim to mobilize, from the bottom-up, the true democrats of Europe. We first establish that Yanis Varoufakis emerged as the political leader of DiEM25 due to his being empowered by an ethical urge to reveal the truth about the EU to its peoples. In Foucauldian terms, we hence justify Varoufakis' ascendancy as the parrhesiastic subject within DiEM25, speaking the truth about the EU to fellow members of the movement, to the whole body of European citizens, as well as to the political actors governing the EU (Varoufakis, 2017). We then evaluate whether his Euroalternativist attempt to reveal the problems of European integration has succeeded in constructing a transnational people.

\section{Rereading the Discourse of DiEM25's Political Leadership}

Thanks to his office as the Greek minister of finance during periods of acute contestation regarding EU decisions by both the national government and the Greek people, Varoufakis had the chance to articulate what he considered to be the truth about the working of the EU institutions. In the midst of a highly mediatized financial crisis, Varoufakis' dissident conduct in the Council of the EU gave voice to concerns about the institutional power of appointed, unelected, technocratic actors in the EU institutions. Varoufakis criticized the EU Commission for its bureaucratic handling of EU policies and governance, arguing that "raw, brutish power [had] taken the place of the democratic process" (BruegelEvents, n.d.). He pointed to the bureaucratic narrowmindedness of the EU institutions concerning innovative solutions to the EU's contemporary challenges. For example, on his innovative idea of an EU antipoverty fund sponsored by European Central Bank (ECB) resources, Varoufakis claimed that this option "offended those in EU that austerity has given them enormous power," implying the Troika mechanism (StartupTV, 2019). Varoufakis' criticism against the modus operandi of EU institutions culminated with the publication of his autobiographical best-seller, Adults in the Room: My Battle with Europe's Deep Establishment (Varoufakis, 2017), focusing on his time as Greece's finance minister.

Either due to having been on the media's spotlight or due to his academic reputation as a professor of economics, Varoufakis undoubtedly ascended in the political realm as a defiant voice speaking the truth about the shortcomings of European integration both courageously and freely, whilst presenting an alternative view of the EU. His leadership style can be explained through political charisma (Pappas, 2016). In the restlessness of formal institutions, the transnational movement has allowed Varoufakis "to defy prevailing worldviews, forging instead new collective entities based on discourses of justification against the established" (Pappas, 2016, p. 379), and by providing a "radical founding of a novel structure of legitimacy" (Pappas, 2016, p. 379). At times of short-term political commitments, Varoufakis' fierce voice and independence can resonate beyond ordinary leadership (Gabriel, 2015). The public resonance of his ideas and his political persona have allowed him to become the central voice of DiEM25 both at national-as the leader of the Greek political party MeRA25-and transnational levels. Furthermore, his leading subject position within the transnational movement may well amount to a hegemonization of DiEM25's discourse. This is evident by Varoufakis' centrality in the Coordinating Collective (CC) of the movement. It also shows in his public appearances, whose number increased during the campaign prior to the 2019 EP elections, as well as in his candidacy for Member of the EP's office in Germany, while organizing the participation of the movement's Greek Electoral Wing (MeRA25) in the same elections. Further, it also shows in the discourse itself, whose boldness and outspokenness reinforces Varoufakis' position as the de facto leader of the movement. Absolute statements such as "the Juncker Plan was a fraud" (BruegelEvents, n.d.), "EU as a Napoleonic project for France" (StartupTV, 2019), "Troika caused the dissolution of the EU" (Varoufakis, 2019a) are not only critical of the EU, they performatively establish Varoufakis as the only political subject among equals who reveals the truth about the misdeeds of the EU. Having the courage to do so, he stands out as the leader of the movement.

The consolidation of Varoufakis' leadership role in DiEM25 is also because he highlighted aspects of truth about the EU and its institutions to mainstream political subjects. He has repeatedly talked about a "very large democratic deficit in the EU" (BBC Newsnight, 2019), condemning the secretive and non-transparent methods of EU institutions-"Eurogroup, astounded by the secrecy" (StartupTV, 2019)-and their inefficiency to deliver prosperity to European citizens"Competition Committee not having done something about the oligopolistic practices of the big supermarkets" (Varoufakis, 2019b). Pushing a progressive Euroalternativist agenda, Varoufakis highlights the need for change in the EU institutions, changes that "will be healing for the whole Europe" or "will be democratizing the EU" (Varoufakis, 2019a). A lot of different political actors claim to speak the truth about the deficient European project, so what makes Varoufakis' discourse exceptional? His discourse comes from the vantage point of a political actor who became directly involved in the EU policy-and decision-making procedures; hence, his claim to the truth acquires a foundation of credibility that may be lacking in other critical voices, and which allows Varoufakis' ascendancy as the parrhesiastic sub- 
ject with the courage to freely criticize the functions and operations of the EU, no matter the political cost. In this manner, Varoufakis's Euroalternativist discourse reinforces his leading role within DiEM25.

\subsection{Euroalternativism and Populism in the Context of True Discourse}

To whom does Varoufakis address the truth about the EU's problems? His speeches first of all target the political subjects governing and managing Greece as an EU member state. In his first speech in the Greek parliament as elected party leader, Varoufakis criticized the conservative government as follows: "At the same time, you will be awarding gifts...to our parasitic oligarchs" (Varoufakis, 2019b). Moreover, Varoufakis renounced the previous government of left-wing SYRIZA for having consented to Troika's demands during the Greek financial crisis, adding that SYRIZA was trying to hold him responsible for the country's austerity (Varoufakis, 2019a). Such comments underline the antagonism between an oppressed people and their ruling economic and political elite. Varoufakis' populist discourse is articulated against Greece's ruling elites by primarily referring to their handling of the positionality of Greece within the European integration project. Being both MeRA25's party leader and DiEM25's leader, Varoufakis manages to pull together in the same chain of equivalence critiques of political clientelism in Europe ("political parties and politicians are largely funded by the oligarchy in every country not just in Germany," StartupTV, 2019), general demands for social justice ("the interest of the few have a disproportionate influence in political narratives," StartupTV, 2019), and public dissatisfaction regarding the inefficiency of EU policies ("you know all too well that Mr. Draghi's arsenal is done," Varoufakis, 2019b).

A number of observations should be highlighted. Varoufakis' populist logic operates simultaneously at two interconnected levels: the Greek national, speaking as the party leader of MeRA25, and the transnational European level, speaking as the leading figure of DiEM25. The two levels become interconnected via the referent object of his discourse, which in both cases is the Euroalternativist need to change the EU's sedimented and unpopular practices of governance. Unlike other commentators on populism arguing that the distinction between the people and its other is moralistic (see Mudde, 2004, for example), meaning a distinction between the pure people and the corrupt other, Varoufakis' populist discourse is based on an ethical performativity of truth-claiming. This means that he establishes his populist claim on the basis that telling the truth about the EU is the right and ethical thing to do, no matter how hard and unpleasant this may be. In his own words, "we will be here to reveal the working-class dystopia, that is predestined to fail, due to memorandum Greece" (Varoufakis, 2019b). Of course, this presupposes firstly an unflinching conviction on behalf of Varoufakis that his version of facts and events is the truth and that this is accepted as such by his audience, the people (see also Moffitt, 2016). MeRA25's electoral success in the Greek elections seems to confirm the public resonance of Varoufakis' claim to the truth about the EU. His success also reinforces his subject position and power status within the domestic political party and by extension within the transnational movement.

Interestingly, Varoufakis negates populism as a strategy to gain political power:

We are here to bury populism. A populism that...the Greek people remember, the PASOK under Simitis, a time when the biggest debt bubble in the Eurozone both public and private was building up, while the Greek people were being told they belonged to the hardcore of Eurozone. (Varoufakis, 2019b)

We witness again how Varoufakis' discourse refers to Greek domestic politics, but in reference to Greece's position within EU structures and mechanisms, unravelling the unspoken truth about Greece's real financial situation. For a better comprehension of the statement, the semantic and political usage of the term 'laikismos' (populism) in Greek politics should be elaborated. The dominant understanding of the word in the Greek language has a negative connotation mainly due to the clientelistic relationships that traditionally develop between the Greek electorate and socioeconomic elites. It is in this manner that Varoufakis refuses the populist label, albeit without denying the importance of the people as the key political actor in radical democratic politics. Moreover, the fact that Varoufakis does not wish to adopt the populist label as part of a long tradition in the Greek context does not mean, nevertheless, that his political logic or logic of articulation is not populist.

\subsection{From Domestic Populism to a Transnational People through the Gates of Euroalternativism?}

The populist call of Varoufakis for real change in the EU's functions, a change that will serve the interests of Europe's peoples, goes beyond Greek borders. DiEM25's responsibility for the democratization of the whole EU is a core feature in his discourse. He pledges solidarity with the British people on Brexit (BruegelEvents, n.d.), sympathizes with families in rural France that cannot pay increased taxation (BruegelEvents, n.d.), and declares that "we will be on the victim's side, not just in Greece, but also in Germany, in France. Because the crisis that started here, in 2008-2010, was transmitted, through the memorandum, to the entirety of the EU." Yanis Varoufakis thus calls upon Europeans to unite against the few, the elites that have coalesced with the politicians and suppress the popular will across the EU.

The leader's populist discourse resonates with the movement's political activities at a pan-European level. Firstly, the movement has broadened its base in Europe 
to over 117,000 members (DiEM25, n.d.-c). Secondly, it maintains a bottom-up approach and actively involves its members in agenda-setting, including initiation of or participation in DSCs or carrying out voluntary work (e.g., translation, communication, etc.) for the movement (DiEM25, n.d.-d). Thirdly, the institutional structure and decision-making procedures within the movement comply with a populist logic of merging the movement's leadership with its popular base. For example, the core political mechanism of the movement, the CC, becomes the representative voice of the movement's membership, as it articulates its stances "in response to events that require a rapid DiEM25 response" (DiEM25, n.d.-e). All the above indicate that DiEM25 and its leadershipwhether this is practiced individually by Varoufakis or collectively by the CC and its members-have employed a Euroalternativist populist discourse that has resonated across Europe.

However, this does not mean that the movement has managed to socially construct a transnational people in the EU. This is primarily due to the populist leadership's limited capacity to use truth-claiming about European integration to socially construct a transnational people. The notion of the people needs indeed a clearly defined constitutive other (de Cleen et al., 2019). In the case of DiEM25 the 'them' are supposed to be a transnational elite as well as an EU in need of change. In both, there is the precocious assumption of a common agreement across Europe regarding who the enemy of the people is. This is erroneous for two reasons. The EU's nature as such is contested and fluid (what we call sui generis) and this extends to the role of the transnational elites. Who are these powerful, oppressing elites that stand against the European peoples' will and what is their exact relationship with the transnational demos? Such ambivalence blurs a clear understanding of the people's constitutive other. Of equal importance, EU citizens do not hold the same understanding of the EU's transnational elites or of their respective roles, as evidenced by the many different versions of Euroscepticism and Euroalternativism which exist (FitzGibbon \& Guerra, 2019). All these point to the fact that we cannot have an accurate picture of the transnational people's political adversary.

Moreover, the parrhesiastic role of the populist leader needs to be highlighted at this point. Within the context of national populism, the populist leader convinces the people of the 'us vs. them' distinction and eventually convinces the body politique that they can speak on behalf of the people and hence represent the people in democratic politics (Laclau, 2005a). This occurs because the populist leader both articulates unheard or silenced public demands, and speaks the truth about the latter being under-represented. The populist leader's truth thus emerges as a revelation and resistance against and despite the power relations embedded in politics. In the context of the hegemonization of DiEM25's discourse by Yanis Varoufakis, in Greece, his success has proved that his political truth can resonate with the people there.
However, there is little empirical evidence that the other peoples of the EU have similarly been united under a common signifier of a transnational people wishing for liberation from the EU Establishment, Brussels' bureaucracy, and elites. Thus, DiEM25's discourse may start transnationally, but its political truth can still fall back to national political outcomes and consequences. Such insights do not fully agree with other scholars' view that DiEM25 is a case of transnational populism; our analysis instead points towards a case of international cooperation between nationally defined populist claims across Europe (see Moffitt, 2017, p. 410). The eventual absence of transnational populism does not mean, however, that we should altogether discount the political strength of transnational progressive Euroalternativism.

\section{Conclusion: Euroalternativist Leadership as a Defender of the People against the Power of the 'Few'}

"We are inspired by a Europe of Reason, Liberty, Tolerance and Imagination made possible by comprehensive Transparency, real Solidarity and authentic Democracy" (DiEM25, n.d.-f). DiEM25 presents a distinctive character in the social and political European context, particularly in terms of its transnational nature and its leadership's discourse. Our analysis has reiterated these two dimensions by investigating the most recent key speeches of the movement's main founder and leader, Yanis Varoufakis. While most of the other studies have sought to examine the movement in terms of its transnational populism, our investigation has focused on Varoufakis' Euroalternativist discourse as the truth about the EU that is able to mobilize the peoples of Europe, from the bottom-up, according to a populist logic. Without being hostile to the EU, the movement's immediate priorities are full transparency in the decision-making at the Council level, "full disclosure of trade negotiation documents, publication of ECB minutes etc.) and...the urgent redeployment of existing EU institutions in the pursuit of innovative policies that genuinely address the crises of debt, banking, inadequate investment, rising poverty and migration" (DiEM25, n.d.-f). After a short time in office as Greek finance minister, Yanis Varoufakis became a credible voice for the progressive Euroalternativist agenda by asking for change in the EU institutions to 'heal' the whole of Europe.

Varoufakis' discourse is based on an ethical performativity of truth-claiming, termed as veridiction (parrhesia). His veridiction addresses a Euroalternativist agenda towards the people, the movement, and the EU institutions. While MeRA25's electoral success in the Greek elections confirms that Varoufakis' claim to the truth about the $\mathrm{EU}$ in Greece resonates with the public, this analysis also points to different conclusions at the transnational level. Our primary insight is that the pursuit of the truth about the problems of EU integration provides more opportunities for a transnational movement. The populist dimension is still attached to domestic national poli- 
tics, whereas critical voices against the EU are becoming more widespread and transnational at the political, mass, and civil society levels. This is because Euroalternativism, or even Euroscepticism, can create alliances across borders, and can aggregate mobilization, particularly at times of crises (see Usherwood, 2017). Progressive Euroalternativist views converge together with similar demands centred on the EU budget and questions of accountability and transparency (FitzGibbon \& Guerra, 2019), the same main issues that mobilize DiEM25's transnationalism. Hence, Euroalternativism is successful in capitalizing on transnationalism, while populism can be limited by national borders. The role of a parrhesiastic leader is to articulate the truth about politics. This truth, in the service of both Euroalternativism and populism in the case of DiEM25 and of Yanis Varoufakis, may be a necessary condition for the social construction of a transnational people across Europe, yet it does not seem to be a sufficient one.

\section{Acknowledgments}

The authors are thankful to the thematic issue's academic editor, the three anonymous reviewers for their helpful comments and constructive criticism, and Raquel Silva for her assistance and support. They would also like to thank their respective institutions for supporting the publication of the article.

\section{Conflict of Interests}

The authors declare no conflict of interests.

\section{References}

BBC Newsnight. (2019). Democracy is the loser both in the UK and in the EU-BBC Newsnight. Yanis Varoufakis. Retrieved from https://www. yanisvaroufakis.eu/2019/01/31/democracy-is-theloser-both-in-the-uk-and-in-the-eu-bbc-newsnight

BruegelEvents. (n.d.). Spitzenkandidaten Series: Yanis Varoufakis. Soundcloud. Retrieved from https:// soundcloud.com/bruegelevents/spitzenkandidatenseries-yanis-varoufakis

de Cleen, B., Glynos, J., \& Mondon, A. (2018). Critical research on populism: Nine rules of engagement. Organization, 25(5), 649-661.

de Cleen, B., Moffitt, B., Panayotu, P., \& Stavrakakis, Y. (2019). The potentials and difficulties of transnational populism: The case of the democracy in Europe Movement 2025 (DiEM2025). Political Studies, 68(1), 146-166. https://doi.org/10.1177/ 0032321719847576

della Porta, D., Kouki, H., \& Fernández, J. (2017). Left's love and hate for Europe: Syriza, Podemos and critical visions of Europe during the crisis. In M. Caiani \& S. Guerra (Eds.), Euroscepticism, democracy and the media: Communicating Europe, contesting Eu- rope (pp. 219-240). Basingstoke: Palgrave Studies in European Political Sociology.

DiEM25. (n.d.-a). What is DiEM? DiEM25. Retrieved from https://diem25.org/what-is-diem25

DiEM25. (n.d.-b). The EU will be democratized. Or it will disintegrate! DiEM25. Retrieved from https:// diem25.org/wp-content/uploads/2016/02/diem25_ english_long.pdf

DiEM25. (n.d.-c). Members. DiEM25. Retrieved from https://internal.diem25.org/members?locale=en

DiEM25 (n.d.-d). How can I volunteer for DiEM25? DiEM25. Retrieved from https://diem25.org/faq/ how-can-i-volunteer-for-diem 25

DiEM25. (n.d.-e). DiEM25 organising principles. DiEM25. Retrieved from https://diem25.org/organisingprinciples

DiEM25. (n.d.-f). DiEM25 short manifesto. DiEM25. Retrieved from https://diem25.org/manifesto-shortversion

DiEM25. (n.d.-g). DiEM25 DSCs. DiEM25. Retrieved from https://internal.diem25.org/dscs/view

Dyrberg, T. B. (2014). Foucault on the politics of parrhesia. Basingstoke: Palgrave Macmillan.

Fanoulis, E., \& Guerra, S. (2017). Anger and protest: Referenda and opposition to the EU in Greece and the United Kingdom. Cambridge Review of International Affairs, 30(4), 305-324.

Final results of Greek national elections. (2019, July 8). Ethnos. Retrieved from https://www.ethnos.gr/ english-version/49313_final-results-greek-nationalelections

FitzGibbon, J. (2013). Citizens against Europe? Civil society and eurosceptic protest in Ireland, the United Kingdom and Denmark. Journal of Common Market Studies, 51(1), 105-121.

FitzGibbon, J., \& Guerra, S. (2019). Transnational euroscepticism vs. transnational euroalternativism. Paper presented at the 2019 European Consortium for Political Research General Conference, Wroclaw, Poland.

FitzGibbon, J., Leruth, B., \& Startin, N. (2017). Euroscepticism as a transnational and pan-European phenomenon: The emergence of a new sphere of opposition. London: Routledge.

Foucault, M. (2010). The government of self and others: Lectures at the Collège de France 1982-1983. Basingstoke: Palgrave Macmillan.

Foucault, M. (2011). The courage of the truth (the government of self and others II): Lectures at the Collège de France 1983-1984. Basingstoke: Palgrave Macmillan.

Gabriel, Y. (2015). The caring leader: What followers expect of their leaders and why. Leadership, 11(3), 316-334.

Kioupkiolis, A., \& Katsambekis, G. (2018). Radical left populism from the margins to the mainstream: A comparison of Syriza and Podemos. In Ó. García Agustín \& M. Briziarelli (Eds.), Podemos and the political cycle: Left-wing populism and anti-establishment poli- 
tics (pp. 201-226). Basingstoke: Palgrave Macmillan. Laclau, E. (2005a). On populist reason. London: Verso Books.

Laclau, E. (2005b). Populism: What's in a name? In F. Panizza (Ed.), Populism and the mirror of democracy (pp. 32-49). London: Verso.

Luxon, N. (2008). Ethics and subjectivity: Practices of selfgovernance in the late lectures of Michel Foucault. Political Theory, 36(3), 377-402.

Marzolini, S., \& Souvlis, G. (2016) An open letter to Yanis Varoufakis. Critical Legal Thinking. Retrieved from http://criticallegalthinking.com/2016/ 04/07/open-letter-yanis-varoufakis

Mazzolini, S., \& Borriello, A. (2018). Southern European populisms as counter-hegemonic discourses? A comparative perspective of Podemos and M5S. In Ó. García Agustín \& M. Briziarelli (Eds.), Podemos and the political cycle: Left-wing populism and antiestablishment politics (pp. 227-254). Basingstoke: Palgrave Macmillan

Moffitt, B. (2016). The global rise of populism: Performance, political style, and representation. Stanford, CA: Stanford University Press.

Moffitt, B. (2017). Transnational populism? Representative claims, media and the difficulty of constructing a transnational 'people.' Javnost-The Public, 24(4), 409-425.

Mudde, C. (2004). The populist zeitgeist. Government and Opposition, 39(4), 541-563.

Panayotu, P. (2017). Towards a transnational populism: A chance for European democracy-The case of DiEM25 (POPULISMUS Working Paper No. 5). Thessaloniki: Populismus. Retrieved from http://www.populismus.gr/wp-content/uploads/ 2017/01/panayotu-final-upload.pdf

Pappas, T. (2016). Are populist leaders "charismatic?" The evidence from Europe. Constellations, 23(3), 378-390.

StartupTV. (2019). Discussing the green new deal for Eu- rope: Startup TV. Yanis Varoufakis. Retrieved from https://www.yanisvaroufakis.eu/2019/07/27/ discussing-the-green-new-deal-for-europe-startuptv

Stavrakakis, Y. (2017). Populism equals nationalism? Beyond reductionism. Paper presented at the 1st Populism Specialist Group PSA Workshop, King's College, London.

Stavrakakis, Y., \& Katsambekis, G. (2014). Left-wing populism in the European periphery: The case of SYRIZA. Journal of Political Ideologies, 19(2), 119-142.

Szczerbiak, A., \& Taggart, P. (2002). The party politics of euroscepticism in EU member states and candidate states (SEI Working Papers No. 51). Brighton: Sussex European Institute. Retrieved from https://www.sussex.ac.uk/webteam/gateway/file. php?name=sei-working-paper-no-51. pdf\&site $=266$

Taggart, P. (1998). A touchstone of dissent: Euroscepticism in contemporary Western European party systems. European Journal of Political Research, 33(3), 363-388.

Usherwood, S. (2017). Modelling transnational and panEuropean Euroscepticism. In J. FitzGibbon, B. Leruth, \& N. Startin (Eds.), Euroscepticism as a transnational and pan-European phenomenon (pp. 14-27). London: Routledge.

Varoufakis, Y. (2017). Adults in the room: My battle with Europe's deep establishment. London: Bodley Head.

Varoufakis, Y. (2019a). Kyverniseis mporei na allazoun, I Chreodouloparoikia omos menei: spot tou MeRA25 gia tis evroekloges [Governments may change, Feudalism yet endures: Spot of MeRA25 for the European elections]. Yanis Varoufakis. Retrieved from https://www.yanisvaroufakis.eu/2019/

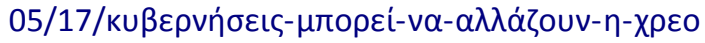

Varoufakis, Y. (2019b). My first speech as MeRA25 leader in Parliament: With English subtitles. Yanis Varoufakis. Retrieved from https://www.yanisvaroufakis. eu/2019/08/06/my-first-speech-as-mera25-leaderin-parliament-with-english-subtitles

\section{About the Authors}

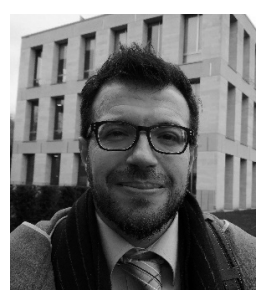

Evangelos Fanoulis is Lecturer in International Relations at Xi'an Jiaotong-Liverpool University. His research interests include democracy and legitimacy in the EU, Foucauldian and Derridean political philosophy, and EU foreign policy. ORCID: https://orcid.org/0000-0001-8749-6982

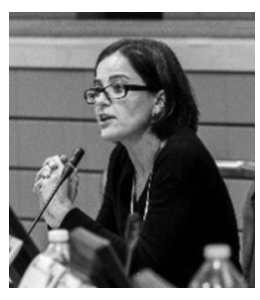

Simona Guerra is Associate Professor of Politics at the School of History, Politics and International Relations, University of Leicester, and Visiting Professor at the College of Europe (Bruges). Her main research interests focus on the domestic politics of EU integration, public Euroscepticism, and populism. ORCID: https://orcid.org/0000-0003-3911-258X 